\title{
Pollen as a component of the diet of Doru luteipes (Scudder, 1876) (Dermaptera: Forficulidade)
}

\author{
R. C. Marucci ${ }^{a}$, I. L. Souza ${ }^{a}$, L. O. Silva ${ }^{b}$, A. M. Auad and S. M. Mendes ${ }^{b *}$ \\ aLaboratório de Controle Biológico, Departamento de Entomologia, Universidade Federal de Lavras - UFLA, \\ Av. Doutor Sylvio Menicucci, 1001, Kennedy, CEP 37200-000, Lavras, MG, Brasil \\ bLaboratório de Entomologia, Centro Nacional de Pesquisa de Milho e Sorgo - EMBRAPA, \\ Rodovia MG-424, Km 45, CP 285 e 151, CEP 35701-970, Sete Lagoas, MG, Brasil \\ 'Laboratório de Entomologia, Centro Nacional de Pesquisa de Gado de Leite - EMBRAPA, \\ Rua Eugênio do Nascimento, 610, Dom Bosco, CEP 36038-330, Juiz de Fora, MG, Brasil \\ *email: simone.mendes@embrapa.br
}

Received: August 15, 2017 - Accepted: March 15, 2018 - Distributed: November 30, 2019

\begin{abstract}
The properties of maize pollen in the diet of Doru luteipes were determined by biological responses of the predator feeding on natural preys and artificial diet. The biological parameters of D. luteipes fed on Spodoptera frugiperda (Smith, 1797) eggs, maize pollen, Rhopalosiphum maidis (Fitch, 1856) + maize pollen and $R$. maidis were assessed. The effect of pollen on artificial diet on the biological variables of the predator nymphs and adults were also evaluated. Time span of nymphal development was greater for D. luteipes exclusively fed on earwigs, with the lowest rate of nymph survival. However, maize pollen plus earwigs in the diet provided the predator's highest survival rate, whilst percentage of fertile females was double when fed on diets composed of $S$. frugiperda and $R$. maidis eggs. Development period decreased when $D$. luteipes nymphs consumed artificial diet plus pollen but there were high fecundity rates (number of laying/female and total egg/female) and a greater percentage of fertile females when they were fed on maize pollen.
\end{abstract}

Keywords: maize, Rhopalosiphum maidis, Spodoptera frugiperda, earwigs, predator.

\section{Pólen como componente da dieta de Doru luteipes (Scudder, 1876) (Dermaptera: Forficulidade)}

\section{Resumo}

Os benefícios do pólen de milho na composição da dieta de Doru luteipes foram determinados por meio das respostas biológicas desse predador alimentado com presas naturais e dieta artificial. Inicialmente, avaliaram-se parâmetros biológicos de D. luteipes alimentados com: ovos de Spodoptera frugiperda (Smith, 1797), pólen de milho, pólen de milho e Rhopalosiphum maidis (Fitch, 1856) e R. maidis. Posteriormente, verificou-se o efeito da presença do pólen em dieta artificial nas variáveis biológicas de ninfas e adultos do predador. O período de desenvolvimento ninfal foi maior para $D$. luteipes alimentado, exclusivamente, com pulgões, sendo esta dieta a que propiciou menor sobrevivência ninfal. No entanto, a adição de pólen de milho na dieta com pulgões proporcionou maior taxa de sobrevivência do predador e, o percentual de fêmeas que ovipositaram foi praticamente o dobro em relação às dietas compostas por ovos de $S$. frugiperda e $R$. maidis. Quando ninfas de D. luteipes consumiram a dieta artificial adicionada com pólen verificou-se redução no período de desenvolvimento ninfal e quando o pólen de milho foi fornecido apenas na fase adulta houve uma maior fecundidade (número de posturas/fêmea e total de ovos/fêmea) e porcentagem de fêmeas que ovipositaram.

Palavras-chave: milho, Rhopalosiphum maidis, Spodoptera frugiperda, tesourinha, predador.

\section{Introduction}

In low prey population density, natural omnivorous enemies are self-sustained by vegetable resources instead of migrating or dying of hunger as may occur with exclusive predators (Shakya et al., 2009). Plant-feeding omnivorous predators may, consequently, remain on the field and avoid the ensuing rapid accumulation of pest-insect populations (Coll, 1998; Eubanks and Denno, 2000; Van Rijn et al., 2002).
The above condition is especially desirable for biological control, mainly when the herbivorous prey population is low, since predators are capable of maintaining the population of pests in equilibrium.

Doru luteipes (Dermaptera: Forficulidae), also known as earwigs, is a key predator in the control of maize pests such as S. frugiperda, Helicoverpa zea (Boddie, 1850) 
(Lepidoptera: Noctuidae) and aphids in general (Reis et al., 1988; Alvarenga et al., 1995). Nymphs consume, on average, 13 eggs and 12 first-instar larvae of $S$. frugiperda, while adults consume 21 caterpillars (Reis et al., 1988). Cruz et al. (1995) found that D. luteipes, during its lifetime, fed 8276 eggs of H. zea (39 eggs/ day), and could be considered capable of suppressing the pest in the corn crop.

The insect is found in fields throughout the year, principally during the development stage of maize, when the occurrence of $S$. frugiperda is greater. D. luteipes may be found not only in corn whorl but also in maize tassels and ears. Eggs are laid on the corn cartridge and on the spike, within the same habitat as S. frugiperda and H. zea, respectively. Humidity is usually high at these sites, or rather, a fundamental condition for the predator's embryonic development (Cruz, 1995). This fact demonstrates its role as predator of larvae and eggs during the entire crop cycle. D. luteipes nymphs and adults prey on specimens in the egg stage and on those in the first instars larval stage (Cruz and Oliveira, 1997).

Due to its dependence on prey density, D. luteipes population increases in maize crops, generally after the population peak of $S$. frugiperda. According to Pasini et al. (2007), exploiting the insect's omnivorous characteristic is a strategy to attract and maintain the predator in the maize fields, making coincident the presence and the occurrence of the pest insect. Within this context, understanding the role of pollen in the development of D. luteipes is fundamental to foreground its use and its manipulation on the field (Nonino et al., 2007).

Since $D$. luteipes is an important predator of corn pests and its occurrence is common in these areas, it is highly relevant to investigate the role of maize pollen in maintaining the predator, especially in the absence and presence of prey in the area. Current assay evaluates the benefits of maize pollen as a component of the diet of the predator D. luteipes.

\section{Material and Methods}

Two bioassays were performed in an acclimatized room at $26 \pm 2^{\circ} \mathrm{C} ; 50 \pm 10 \%$ and 12-hour photophase. Insects had been bred at Embrapa Maize and Sorghum and the breeding of $D$. luteipes followed methodology by Cruz (2009), S. frugiperda, following Mendes et al. (2011) and aphid R. maidis (Hemiptera: Aphididae) according to Fonseca et al. (2005). Maize pollen was collected in fields with conventional maize (untreated seeds) production of Embrapa Maize and Sorghum.

Bioassay 1: Response to pollen intake by $D$. luteipes nymphs fed on pest insects of maize.

Four diets were evaluated: 1) eggs of $S$. frugiperda, 2) maize pollen, 3) maize pollen $+R$. maidis and 4) $R$. maidis. Recently-hatched nymphs of $D$. luteipes were individualized and placed in petri dishes with $5 \mathrm{~cm}$ diameter. Respective diets of each treatment were provided ad libitum. The diet was renewed daily throughout the nymphal phase. After the emergence of adults, the couples were placed in dishes with the same diets and they were evaluated daily for survival and egg-laying/couple rates. The design was completely randomized with fifty-eight repetitions and the parameters assessed in current bioassay comprised duration and survival of the nymphal stage, longevity of adults and percentage of fertile females. Data underwent analysis of variance (ANOVA) and means compared by Tukey's test $(\mathrm{p} \leq 0.05)$.

Bioassay 2: Response to intake of pollen by $D$. luteipes nymphs and adults fed on artificial diet.

Newly hatched nymphs of $D$. luteipes were individualized and placed in $50 \mathrm{~mL}$ plastic cups covered with acrylic lids, containing a cotton swab wetted in distilled water and one folded fan-type paper. Half of the nymphs (60) were fed with artificial diet (diet 1) and the other half (60) with artificial diet plus maize pollen (diet 2). Diet was changed twice a week during the nymphal stage and the earwigs were assessed daily. After the emergence of adults, the same diet combination (diet 1 and 2) was provided to adults originated from the nymphs fed on artificial diet and to adults from nymphs fed on artificial diet plus pollen.

Couples were formed and selected according to the number of adults which survived in each diet so that the following matches were tested by the bioassay: 1) DD: artificial diet in the juvenile and adult phases; 2) DDP: artificial diet in the juvenile phase and diet plus pollen in the adult phase, 3) DPD: artificial diet plus pollen in the juvenile phase and diet alone in the adult phase; 4) DPDP: artificial diet plus pollen in the juvenile and adult phases. The design was completely randomized with fifteen repetitions and the following biological parameters were assessed: duration of the nymphal period and of the pre-oviposition period, longevity of adults, percentage of fertile females; total number of eggs per female, number of eggs per egg laying and interval between egg laying. Data underwent analysis of variance (ANOVA) and means were compared by Tukey's test $(\mathrm{p} \leq 0.05)$.

\section{Results and Discussion}

\subsection{Response to consume of pollen by D. luteipes fed with insects pests of maize}

When the survival of $D$. luteipes nymphs fed on diets available on the field, such as exclusive feed to aphids, $S$. frugiperda eggs and aphids plus maize pollen were assessed, lower survival rates in the nymphal phase were reported for nymphs which were kept exclusively on $S$. frugiperda eggs and for aphids. Other diets with pollen only and pollen plus $R$. maidis featured $64.4 \%$ survival (Table 1). Thus, pollen in the diet of nymphs provides them extra nutrients necessary to their survival and an exclusive diet with $S$. frugiperda eggs or aphids probably does not satisfy the nutritional requirements of the predator in the field.

Pasini et al. (2007) reported $100 \%$ viability of nymphal phase for Doru sp. fed on diet based on Bombyx mori (Linnaeus, 1758) (Lepidoptera: Bombycidae) mixed with pollen of narrow-leaved cattail (Typha angustifolia L.), 
Table 1. Mean duration of nymphal period $( \pm \mathrm{SE})$, survival percentile $( \pm \mathrm{SE})$ and percentile of fertile females $( \pm \mathrm{SE})$ of Doru luteipes kept on four diets $\left(26 \pm 2^{\circ} \mathrm{C}, \mathrm{RH}=50 \pm 10 \%\right.$; photophase $=12$ hours $)$.

\begin{tabular}{lccc}
\hline \multicolumn{1}{c}{ Diet } & Nymphal period (days) & Survival (\%) & Fertile females (\%) \\
\hline Eggs of Spodoptera frugiperda & $33.0 \pm 1.11 \mathrm{~b}$ & $33.6 \pm 8.08 \mathrm{~b}$ & $35.7 \pm 9.07 \mathrm{~b}$ \\
Maize pollen & $31.2 \pm 0.89 \mathrm{~b}$ & $64.4 \pm 8.02 \mathrm{a}$ & $63.3 \pm 8.01 \mathrm{a}$ \\
Pollen and Rophalosiphum maidis & $30.3 \pm 0.59 \mathrm{~b}$ & $64.4 \pm 9.72 \mathrm{a}$ & $68.3 \pm 8.73 \mathrm{a}$ \\
R. maidis & $37.6 \pm 2.01 \mathrm{a}$ & $31.1 \pm 7.12 \mathrm{~b}$ & $31.7 \pm 7.50 \mathrm{~b}$ \\
$\mathrm{CV}(\%)$ & $15 \%$ & $30 \%$ & $66 \%$ \\
$\mathrm{P}$ & 0.0000 & 0.0004 & 0.0051 \\
$\mathrm{~F}$ & 10.85 & 7.318 & 4.753 \\
\hline
\end{tabular}

Means $( \pm \mathrm{SE})$ followed by the same letter in the columns do not differ by Tukey's test $(5 \%)$.

highlighting the importance of feed with pollen for nymph survival. Although T. angustifolia pollen plus diet may supply the lack of certain nutrients, the use of commercial bee pollen alone was nutritionally inadequate. According to Haas (2012), examination of the intestinal contents of Doru sp. collected on the field revealed fragments of arthropods, pollen, fungus spores and plant fragments. The above datum underscores the selection of omnivorous diet under field conditions besides the generalist feeding characteristics of Doru sp.

Although data on the development period of the nymphal phase in current study corroborates those by Pasini et al. (2007) for D. luteipes fed on S. frugiperda eggs (30.8 days), they registered a greater survival of the predator $(75 \%)$. Probably, high survival rates reported by these authors may be associated to the environment or to relative humidity provided by the soft drink straw containing moist cotton used as shelter for the nymphs. Since the authors also reported high percentage of smaller adults with deformations in the cercus, this fact indicated that the exclusive diet with $S$. frugiperda eggs may be nutritionally inappropriate.

Survival data are similar to those by Reis et al. (1988) with $32.7 \%$ for $D$. luteipes fed on $S$. frugiperda eggs. Results reveal that, although $S$. frugiperda eggs are the main prey of D. luteipes in maize (Cruz, 1995), an exclusive diet with the prey's eggs may not be enough to meet the nutritional demands of the omnivorous predator. Maize pollen may be an alternative source of energy for the predator or one component of a wider diet.

The nymphs' development period was similar when they were fed on $S$. frugiperda eggs, maize pollen and maize pollen plus aphids, but greater when nymphs were fed only on aphids (Table 1). As a rule, the higher the development period, the less suitable the diet is for the insect, since it takes a longer period to complete the cycle (Panizzi and Parra, 2013a). Consequently, aphids would be preys of low nutritional quality. Alvarenga et al. (1995) registered that the nymphal period of $D$. luteipes ranged between 37.5 and 50.1 days when nymphs were fed on Schizaphis graminum (Rondani, 1852) (Hemiptera: Aphididae) kept in different sorghum genotypes. The rate is similar to that obtained in current study for diet based on
$R$. maidis with a nymphal period of 37.6 days, or rather, higher than that in other diets under analysis.

The above data reinforce the hypothesis that omnivorism on the field may occur not only in prey scarcity conditions, but as a form of nutritional supplementation. Supplementation of the predator's diet reduces the intake of prey due to time constraints, nutritional limitations or finite capacity of the intestine (Sabelis, 1990; Jeschke, 2007). However, these implications need to be studied further in the case of D. luteipes, especially within the possible trophic interactions in maize crops.

When the percentage of fertile females of $D$. luteipes is evaluated, it has been reported that in the case of couples fed on preys only, S. frugiperda eggs and aphid R. maidis, lower female percentages laid eggs. On the other hand, nearly twice as many females laid eggs when on diets, comprising maize pollen alone or $R$. maidis plus pollen (Table 1). In this case, pollen could supply them with critical or extra nutrients necessary for egg production or over-wintering (Hagen, 1962). Eubanks and Denno (2000) consider lepidoptera eggs as high quality nutrition prey for generalist predators, in contrast to aphids considered of low nutritional quality. However, prey mobility rather than prey nutritional quality seems to be the most important criterion used by Geocoris punctipes (Say, 1832) (Heteroptera: Geocoridae) to select prey. Results in current study reinforce the hypothesis that exclusive predation may be insufficient to meet the nutritional demands of omnivorous predators, which require nutrients obtained from plants to supplement their diet.

\subsection{Response to pollen intake by D. luteipes nymphs and adults fed on artificial diet}

Artificial diet added to maize pollen during the juvenile phase significantly decreased the duration of the nymphal period (Table 2). Data corroborate those in the first bioassay, in which the addition of pollen also reduced the predator's development period. Oliveira et al. (2010) reported that larvae of Chrysoperla externa (Hagen, 1861) (Neuroptera: Chrysopidae) complete the juvenile stage feeding exclusively on pollen. In current study, the addition of pollen to the diet in the juvenile stage reduced the development period, which is an important variable for the maintenance of the species on the field. 
Table 2. Nymphal period $( \pm$ SE), total number of eggs / female $( \pm$ SE), number of ovipositions/female $( \pm$ SE) and percentage of fertile females $( \pm \mathrm{SE})$ of Doru luteipes after alimentation using four combinations of artificial diet and artificial diet + pollen $\left(26 \pm 2^{\circ} \mathrm{C}, \mathrm{RH}=50 \pm 10 \%\right.$ and photophase of 12 hours $)$.

\begin{tabular}{ccccc}
\hline Diet & $\begin{array}{c}\text { Nymphal period } \\
\text { (days) }\end{array}$ & $\begin{array}{c}\text { Total number of } \\
\text { eggs / female }\end{array}$ & $\begin{array}{c}\text { Number of } \\
\text { ovipositions / female }\end{array}$ & $\begin{array}{c}\text { Fertile females } \\
\text { (\%) }\end{array}$ \\
\hline DD & $37.4 \pm 0.45 \mathrm{a}$ & $42.23 \pm 7.67 \mathrm{ab}$ & $2.31 \pm 0.40 \mathrm{ab}$ & $39.28 \pm 0.20 \mathrm{ab}$ \\
DDP & - & $65.52 \pm 9.88 \mathrm{a}$ & $3.33 \pm 0.30 \mathrm{a}$ & $59.37 \pm 0.35 \mathrm{a}$ \\
DPD & - & $22.86 \pm 5.55 \mathrm{~b}$ & $1.43 \pm 0.16 \mathrm{~b}$ & $31.25 \pm 0.60 \mathrm{~b}$ \\
DPDP & $34.5 \pm 0.61 \mathrm{~b}$ & $45.81 \pm 6.88 \mathrm{ab}$ & $2.54 \pm 0.29 \mathrm{ab}$ & $56.25 \pm 0.55 \mathrm{ab}$ \\
CV (\%) & 14.96 & 61.24 & 30.87 & 11.22 \\
P & 0.000 & 0.0125 & 0.0073 & 0.0139 \\
F & 14.606 & 4.014 & 4.498 & 4.253 \\
\hline
\end{tabular}

Means ( \pm SE) followed by the same letter in the columns do not differ by Tukey's test (5\%). DD: artificial diet in the adult and nymphal stages; DDP: artificial diet in the nymphal stage and artificial diet + pollen in the adult stage; DPD: artificial diet + pollen in the nymphal stage and artificial diet in the adult stage; DPDP: artificial diet + pollen in the nymphal and adult stages.

There was no significant difference for feeding on artificial diet with and without pollen for adult longevity parameters $(\mathrm{P}=0.6149, \mathrm{~F}=0.603)$, interval between oviposition $(\mathrm{P}=0.6270, \mathrm{~F}=0.653)$, number of eggs/oviposition $(\mathrm{P}=0.5139, \mathrm{~F}=0.775)$ and length of the pre-oviposition period $(\mathrm{P}=0.2011, \mathrm{~F}=1.594)$. Mean longevity of $D$. luteipes adults was 78.11 days; mean interval between oviposition was 23.97 days; average number of eggs/oviposition was 18.12 ; pre-oviposition period comprised 30.00 days.

On the one hand, a greater rate in eggs/female, total number of eggs and percentage of fertile females were registered when pollen was added to artificial diet only in the adult stage (DDP), but did not differ from the diet without pollen (DD) or with pollen (DPDP). There was a smaller number of eggs per female, total number of eggs and percentage of fertile females when pollen was increased only in the insect's nymphal stage (DPD) (Table 2). Results demonstrate the key role of supplementary pollen when given to $D$. luteipes adults.

Plant pollen is a source of energy that provides proteins, minerals, lipids and vitamins (Pereira et al., 2006). Corn pollen is abundant during anthesis, and a number of natural enemies feed on corn pollen during this period (Pilcher et al., 1997). Lundgren and Wiedenmann (2004) registered that corn pollen contains sugars, relatively high levels of starch (primarily amylopectin), amino acids and proteins, such as adenine and choline, lipids and phytosterols and phosphorus, potassium and other inorganic minerals, but contains almost no carotenoid pigments. Corn pollen is yellow because of the flavonoid pigment quercetin and its derivatives. This is a biochemical feature that is relatively unique to corn pollen. Owing to this rich composition, maize pollen constitutes an appropriate source for the nymphs' survival and for female fertility.

Current results indicate pollen effect on the diet of adult $D$. luteipes due to its contribution to increase in female fertility, with more eggs laid and a greater number of eggs/oviposition. The literature shows that pollen intake improves the fertility of other insect groups (Van Rijn et al.,
2002). Thus the effects of corn pollen on the fitness and fecundity of pollen-reared $D$. luteipes adults could be investigated and exploited thoroughly.

According to Guerreiro et al. (2003), only D. luteipes adults may be found in the initial stage of maize crop, probably migrants from other cultures, attracted by the first ovipositions of $S$. frugiperda. Nymphs are found later in the crop, between 30 and 60 days after maize emergence, near plant tassels, feeding on other pests, such as aphids, or on nectar and pollen, which are alternative sources of energy. This fact causes increased efficiency of field predators, because pollen not only reduces nymphs' cycle but also increases female fertility.

According to Panizzi and Parra (2013b), nutrient supplementation to attract natural enemies is an insect management strategy with strong ecological and nutritional appeal. These factors must be taken into account in the establishment and maintenance of natural enemies with great voracity, in maize fields, as in the case of $D$. luteipes that feeds on eggs, small larvae of Lepidoptera and aphids to improve reproductive performance of adults, and, consequently increase its occurrence and density in the area.

Thus, pollen intake by D. luteipes should not be considered optional, but necessary in periods with low availability of prey, and supplementary to improve adult fertility. Furthermore, pollen intake could enhance D. luteipes nymphs and adults' performance on the field and should be measured.

This aspect is important to improve biological control strategies in maize and in other crops in which $D$. luteipes acts is a predator.

\section{Conclusion}

Maize pollen added to the diet of $D$. luteipes contributes towards higher survival nymphs and adult fertility when compared to the exclusive consumption of natural prey (S. frugiperda and R. maidis). In fact, pollen consumption by the adult is related to increased fecundity and fertility in females. 


\section{References}

ALVARENGA, C.D., VENDRAMIM, J.D. and CRUZ, I., 1995. Biologia e predação de Doru luteipes (Scud.) sobre Schizaphis graminum (Rond.) criado em diferentes genótipos de sorgo. Anais da Sociedade Entomológica do Brasil, vol. 24, no. 3, pp. 523-531.

COLL, M., 1998. Living and feeding on plants in predatory Heteroptera. In: M. COLL, J.R. RUBERSON, eds. Predatory Heteroptera: Their ecology and use in biological control. Proceedings, Thomas say publications in entomology. Lanham: Entomological Society of America, pp. 89-129.

CRUZ, I. and OLIVEIRA, A.C., 1997. Flutuação populacional do predador Doru luteipes Scudder em plantas de milho. Pesquisa Agropecuária Brasileira, Brasília, vol. 32, no. 4, pp. 363-368.

CRUZ, I., 1995. Manejo Integrado de pragas de milho com ênfase para o controle biológico. In A.B. FILHO, ed. Anais do IV Ciclo de Palestras sobre Controle Biológico de Pragas, Campinas: Sociedade Entomológica do Brasil, pp. 48-92.

CRUZ, I., 2009. Métodos de criação de agentes entomófagos de Spodoptera frugiperda. In: V.H.P. BUENO, ed. Controle biológico de pragas: produção massal e controle de qualidade. Lavras: UFLA, pp. 237-275.

CRUZ, I., ALVARENGA, C.D. and FIGUEIREDO, P.E.F., 1995. Biologia de Doru luteipes (Scudder) e sua capacidade predatória de ovos de Helicoverpa zea (Boddie). Anais da Sociedade Entomológica do Brasil, vol. 24, no. 2, pp. 273-278.

EUBANKS, M.D. and DENNO, R.F., 2000. Health food versus fast food: the effects of prey quality and mobility on prey selection by a generalist predator and indirect interactions among prey species. Ecological Entomology, London, vol. 25, no. 2, pp. 140-146. http://dx.doi.org/10.1046/j.1365-2311.2000.00243.x.

FONSECA, A.R., CRUZ, I., CARVALHO, C.F. and SOUZA, B., 2005. Resistência de genótipos de sorgo ao pulgão Rhopalosiphum maidis (Fitch, 1856) Hemiptera: Aphididae. II. Teste de confinamento. Revista Brasileira de Milho e Sorgo. Sete Lagoas, vol. 4, no. 3, pp. 323-334.

GUERREIRO, J.C., BERTI FILHO, E. and BUSOLI, A.C., 2003. Ocorrência estacional de Doru luteipes na cultura do milho em São Paulo, Brasil. Manejo Integrado de Plagas y Agroecología, vol. 70 , pp. 46-49.

HAAS, F., 2012. Dermaptera. In: J.A. RAFAEL, G.A.R. MELO, C.J.B. CARVALHO, S.A., CASARI, and R. CONSTANTINO, eds. Insetos do Brasil: Diversidade e Taxonomia. Ribeirão Preto: Holos, pp. 297-305.

HAGEN, K.S., 1962. Biology and ecology of predaceous Coccinellidae. Annual Review of Entomology, vol. 7, no. 1, pp. 289-326. http://dx.doi.org/10.1146/annurev.en.07.010162.001445.

JESCHKE, J.M., 2007. When carnivores are "full and lazy". Oecologia, vol. 152, no. 2, pp. 357-364. http://dx.doi.org/10.1007/ s00442-006-0654-2. PMid:17294218.

LUNDGREN, J.G. and WIEDENMANN, R.N., 2004. Nutritional suitability of corn pollen for the predator Coleomegilla maculata (Coleoptera: Coccinellidae). Journal of Insect Physiology, vol. 50, no. 6, pp. 567-575. http://dx.doi.org/10.1016/j.jinsphys.2004.04.003. PMid:15183287.

MENDES, S.M., BOREGAS, K.G.B., LOPES, M.E., WAQUIL, M.S. and WAQUIL, J.M., 2011. Respostas da lagarta-do-cartucho a milho geneticamente modificado expressando a toxina Cry $1 \mathrm{~A}(\mathrm{~b})$. Pesquisa Agropecuária Brasileira, Brasília, vol. 46, no. 3, pp. 239-244. http://dx.doi.org/10.1590/S0100-204X2011000300003.

NONINO, C.M., PASINI, A. and VENTURA, M.U., 2007. Atração do predador Doru luteipes (Scudder) (Dermaptera: Forficulidae) por estímulos olfativos de dietas alternativas em laboratório. Ciência Rural, Santa Maria, vol. 37, no. 3, pp. 623-627. http://dx.doi.org/10.1590/S0103-84782007000300004.

OLIVEIRA, S.A., SOUZA, B., AUAD, A.M. and CARVALHO, C.A., 2010. Can larval lacewings Chrysoperla externa (Hagen) (Neuroptera, Chrysopidae) be reared on pollen? Revista Brasileira de Entomologia, vol. 54, no. 4, pp. 697-700. http://dx.doi. org/10.1590/S0085-56262010000400024.

PANIZZI, A.R. and PARRA, J.R.P. 2013a. A evolução das dietas artificiais e suas interações em Ciência e Tecnologia. In: A.R. PANIZZI, and J.R.P. PARRA, eds. Bioecologia e nutrição de insetos: base para o manejo integrado de pragas. 2. ed. Brasília: Brasília: Embrapa Informação Tecnológica, pp. 1164.

PANIZZI, A.R. and PARRA, J.R.P. 2013b. Introdução à bioecologia e nutrição de insetos como base para o manejo integrado de pragas. In: A.R. Panizzi and J.R.P. Parra, eds. Bioecologia e nutrição de insetos: base para o manejo integrado de pragas. 2. ed. Brasília: Embrapa Informação Tecnológica, pp. 1164

PASINI, A., PARRA, J.R.P. and LOPES, J., 2007. Dieta artificial para criação de Doru luteipes (Scudder) (Dermaptera: Forficulidae), predador da lagarta-do-cartucho do milho, Spodoptera frugiperda (J.E. Smith) (Lepidoptera: Noctuidae). Neotropical Entomology, Londrina, vol. 36, no. 2, pp. 308-311. PMid:17607467.

PEREIRA, F.M., FREITAS, B.M., VIEIRA NETO, J.M., LOPES, M.T.R., BARBOSA, A.L. and CAMARGO, R.C.R., 2006. Desenvolvimento de colônias de abelhas com diferentes alimentos protéicos. Pesquisa Agropecuária Brasileira, vol. 41, no. 1, pp. 1-7. http://dx.doi.org/10.1590/S0100-204X2006000100001.

PILCHER, C.D., OBRYCKI, J.J., RICE, M.E. and LEWIS, L.C., 1997. Preimaginal development, survival, and field abundance of insect predators on transgenic Bacillus thuringiensis corn. Environmental Entomology, vol. 26, no. 2, pp. 446-454. http:// dx.doi.org/10.1093/ee/26.2.446.

REIS, L.L., OLIVEIRA, L.J. and CRUZ, I., 1988. Biologia e potencial de Doru luteipes no controle de Spodoptera frugiperda. Pesquisa Agropecuária Brasileira, Brasília, vol. 23, no. 4, pp. 333-342.

SABELIS, M.W., 1990. How to analyse prey preference when prey density varies? A new method to discriminate between effects of gut fullness and prey type composition. Oecologia, vol. 82, no. 3, pp. 289-298. http://dx.doi.org/10.1007/BF00317473. PMid:28312701.

SHAKYA, S., WEINTRAUB, P.G. and COLL, M., 2009. Effect of pollen supplement on intraguild predatory interactions between two omnivores: the importance of spatial dynamics. Biological Control, vol. 50, no. 3, pp. 281-287. http://dx.doi.org/10.1016/j. biocontrol.2009.04.012

VAN RIJN, P.C., VAN HOUTEN, Y.M. and SABELIS, M.W, 2002. How plants benefit from providing food to predators even when it is also edible to herbivores. Ecology, vol. 83, no. 10, pp. 2664-2679. https://doi:10.1890/0012-9658(2002)083[2664:HP BFPF]2.0.CO;2. 